\title{
Finnish records of discomycetes: Unguicularia equiseti sp.nov. and Albotricha laetior
}

\author{
SEPPO HUHTINEN
}

\begin{abstract}
HUHTINEN, S. 1985: Finnish records of discomycetes: Unguicularia equiseti sp.nov. and Albotricha laetior. - Karstenia 25: 17-20.

A new species, Unguicularia equiseti Huhtinen, characterized by its branched hairs, is described from SW Finland. The species grows on blackened stems of Equisetum sylvaticum L. A new collection of a rare discomycete, Albotricha laetior (Karst.) Raitv., is described and discussed, and the species is considered lignicolous. A warning is given that certain mountants currently in common use frequently have a shrinking effect. In many cases sections revived in these mountants fail to regain their natural dimensions. The taxonomic importance of this phenomenon is briefly discussed.
\end{abstract}

Seppo Huhtinen, Department of Biology, University of Turku, SF-20500 Turku. Finland

Unguicularia equiseti Huhtinen sp.nov.

- Figs. $1-5$

Apothecia cupulata, breviter stipitata, diametro usque ad $0.4 \mathrm{~mm}$, recentia alba vel pallide brunnea, minuter pilosa. Excipulum externum textura prismatica, cellulis $10 \times 3 \mu \mathrm{m}$ prope marginem, tenuiter tunicatis, cellulis deorsum $15 \times 7 \mu \mathrm{m}$, aliquantum crassotunicatis, hyalinis vel brunneoincrustatis. Pili abundantes, usque ad $48 \mu \mathrm{m}$ longi, ramosi, omnino solidi praeter in basi, in iodo non colorati, leves. Asci 33-37 $\times 4-5 \mu \mathrm{m}$, amyloidei. Sporae 6.5-8.0 $\times 1.5-1.9 \mu \mathrm{m}$, oblongocylindratae, rectae vel minuter curvatae, hyalinae, non septatae, guttulatae. Paraphyses filiformes, 1 rm latae.

Holotypus: Finland. Prov. Satakunta: Punkalaidun, Vanttila, grid $27^{\circ} \mathrm{E} 6791: 282$, on dead stems of Equisetum sylvaticum L., 2.VII.1983 Huhtinen 83/48 (TUR, isotypi in L, DAOM, PR and TAA).

Apothecia cupulate, shortly stipitate, flanks minutely hairy throughout, up to $250(-400) \mu \mathrm{m}$ in diam when fresh, stipe ca. $50 \times 90 \mu \mathrm{m}$; white in all parts or stipe basally brownish, often turning totally brownish when drying, dull under UV light (366 nm). Ectal excipulum of textura prismatica; cells regular in shape and with slightly thickened, hyaline walls, ca. $10 \times$ $3 \mu \mathrm{m}$ near the margin, ca. $15 \times 7 \mu \mathrm{m}$ in lower parts, the encrustation responsible for the brownish colouring, deep orange brown under microscope, not dissolving in Melzer's reagent or $\mathrm{KOH}(20 \%)$.

Hairs numerous, up to $48 \mu \mathrm{m}$ long, rarely unbranched, typically with numerous protuberances and branches, but one side of the hair unbranched, the refractive parts solid, lumen restricted to the base. Hairs smooth when fresh, occasional encrustation restricted to the non-refractive part, negative in cotton blue or Congo red, indextrinoid, stable in Melzer's reagent, glassiness lost and hairs fragmented in unheated $\mathrm{KOH}(5-7 \%)$.
Asci cylindrical, eight-spored, $33-37 \times 4-5 \mu \mathrm{m}$, amyloid without $\mathrm{KOH}$ pretreatment, base with indistinct croziers. Spores irregularly biseriate, oblongellipsoid, typically straight, $6.5-8.0 \times 1.5-1.9 \mu \mathrm{m}$, hyaline, smooth, aseptate, regularly biguttulate both when fresh and dry. Paraphyses filiform, $1 \mu \mathrm{m}$ wide, not exceeding the asci.

Paratypi: Finland. Satakunta: Punkalaidun, type loc., 4.VI.1983 Huhtinen $83 / 14$; 25.VIII.1983 Huhtinen 83/292; 27.V.1984 Huhtinen $84 / 34$; 13. X.1984 Huhtinen $84 / 257$; grid $6791: 282$, 2.VIl.1983 Huhtinen 83/50; grid 6790/282, 2.VII.1983 Huhtinen 83/51. - Varsinais-Suomi: Rymättylä, Aaslaluoto, N shore of Sydänmaanjärvi, grid 6698:219, 5.VII.1983 Laine. All on Equisetum sylvaticum, TUR.

The present species has been collected in two separate areas in SW Finland. All the specimens derive from Equisetum sylvaticum and a search on other species of Equisetum has been unsuccesful. Due to the characteristically branched hairs, $U$. equiseti is easily recognized under the microscope. These hairs distinguish the species clearly from any other hyaloscyphaceous fungus known to me.

Recently both Raschle (1977) and Korf \& Kohn (1980) have stressed the importance of the use of $\mathrm{KOH}$ in the classification of genera with glassy hairs. The present species does not fit very well with these new ideas. $U$. equiseti combines unstable glassiness with solid hairs lacking a lumen. If the $\mathrm{KOH}$ reaction (10 $\%$ ) were preferred to the hair morphology in the taxonomy, the species should be placed in a new subgenus in Urceolella sensu Korf \& Kohn. By preferring the hair morphology, I believe that I have gained a more natural concept. The stability of the glassiness depends on the concentration of the $\mathrm{KOH}$. Raschle (1977) reported that the hairs in the genus Unguicularia are stable in $5 \% \mathrm{KOH}$. With this concentration some changes occur in the hairs of $U$. 

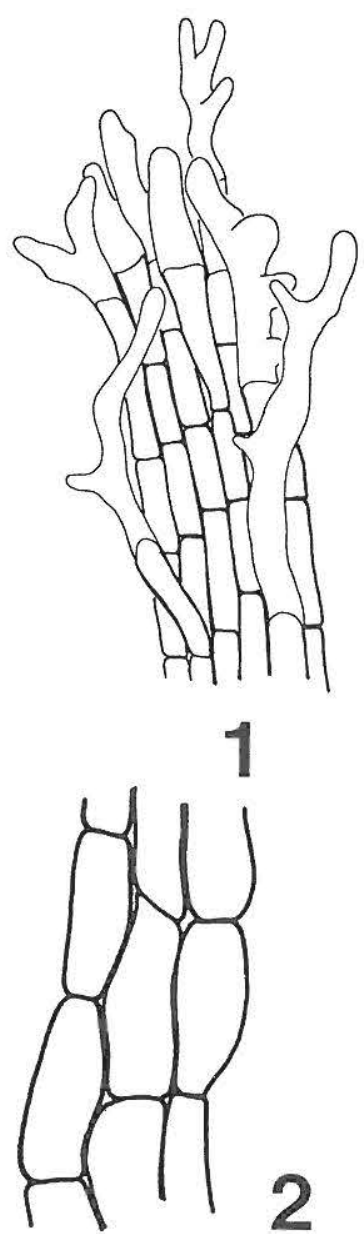
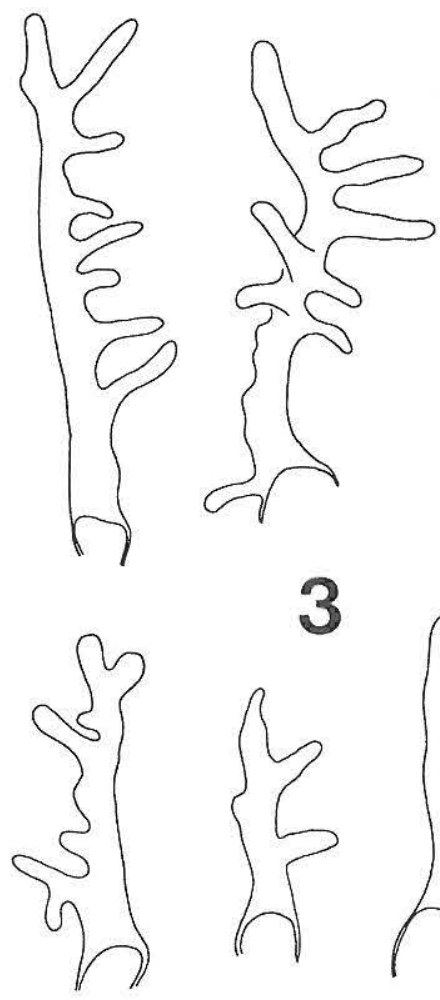
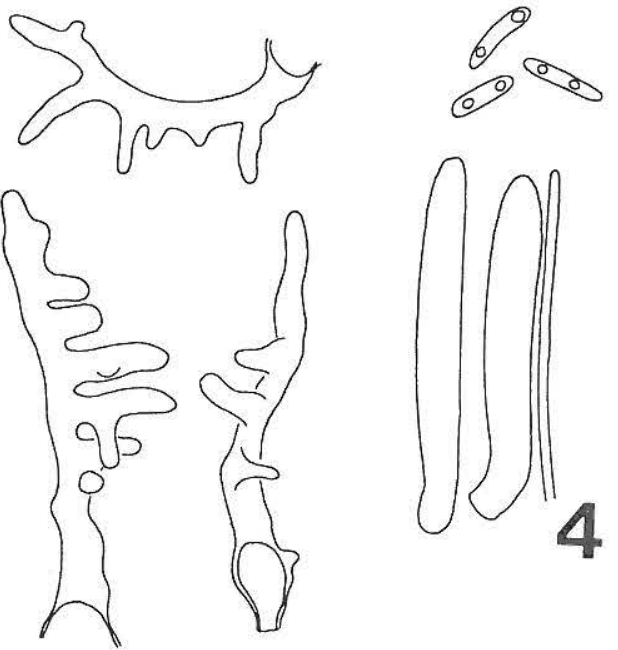
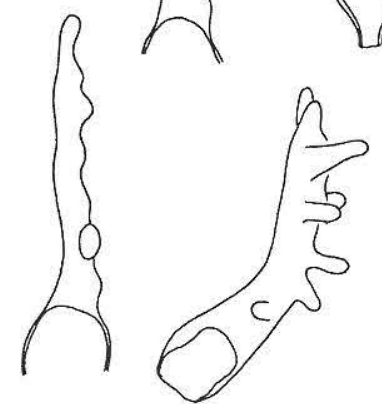

\section{$0.2 \mathrm{~mm}$}
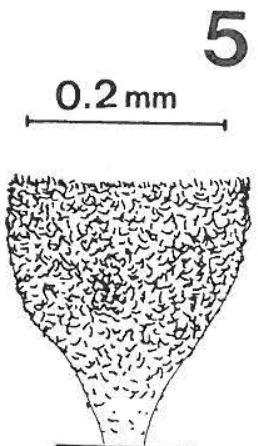

Figs. 1-5. Unguicularia equiseti, scale $50 \mu \mathrm{m}$, all from holotype. - 1: Margin. - 2: Ectal excipulum. - 3: Hairs. -4: Asci, spores and a paraphysis. - 5: Apothecium.

equiseti, but most hairs remain intact. The use of unheated $6 \% \mathrm{KOH}$ results in almost immediate loss of glassiness and in fragmentation of the hairs. The five per cent limit used by Raschle in his key thus seems to be valid here, but does not necessarily reflect any structural relationship in the hair wall material. Another species of the genus, Unguicularia millepunctata (Lib.) Dennis, has hairs that are structurally stable even in heated $40 \% \mathrm{KOH}$. And with Urceolella carestiana (Rabenh.) Dennis, I found that the hairs were stable in $4 \% \mathrm{KOH}$ but lost their glassiness immediately in unheated $5 \% \mathrm{KOH}$. In view of its consistently solid hairs, the present new species cannot belong to Urceolella. Classification stressing the significance of the $\mathrm{KOH}$ reaction would lead to minimal variation between the genera and maximal within.

In the type locality this species is found in great numbers early in the season. The phenology seems to be approximately the same as that of Gyromitra esculenta, peak fruiting occurring in May. In 1984 some apothecia were found in late October.
Here I would also like to discuss a methodological problem of taxonomic importance. In numerous taxa of both the Helotiales and Pezizales, I have observed that the mountants commonly in use have a shrinking effect. When dried material is revived with Melzer's reagent or lactic acid, the sections do not always regain their original dimensions. This can be concluded from the results of adding these mountants to natural or water mounts of fresh apothecia. Shrinkage of 5$15 \%$ takes place immediately, due to a loss of turgor in the cells. This reaction is common among the discomycetous fungi, at least whenever thin or moderately thick-walled, living structures are measured. Similar but even more pronounced shrinkage has been noted by Döbbeler (1984).

A major problem is posed by the lack of exact information on the procedures used earlier by various authors. Far-reaching conclusions drawn from minor differences in earlier descriptions will only create uncertainty in the taxonomy. In such cases original material should always be checked whenever possible. 
Exact mounting procedures should be indicated in every critical case, i.e. when taxa are separated on the basis of a hiatus representing less than ca. 20 per cent of the magnitude.

Albotricha laetior (Karst.) Raitv. - Figs. 6-12 Material studied: Finland. Satakunta: Punkalaidun, Vanttila, grid $27^{\circ} \mathrm{E} 6790: 282$, decorticated twig of Salix caprea by a dense stand of Rubus idaeus (collected in juvenile stage, kept in moist chamber until mature), 23.IV.1984 Huhtinen 84/14 (TUR). - Etelä-Häme: Tammela, Mustiala, Rubus idaeus, 8.VII.1869 Karsten 2503 (H, holotype), 2504 (H, isotype).

Apothecia up to $500 \mu \mathrm{m}$ in diam when fresh, fleshy, shortly stipitate, disc luteous when fresh, outside totally hairy and white, in general appearance much resembling Lachnum bicolor. Ectal excipulum hyaline, cells roundish or somewhat prismatic, $8-15 \mu \mathrm{m}$ in diam or ca. $12 \times 6 \mu \mathrm{m}$, walls $0.5-0.7 \mu \mathrm{m}$ thick in lactic acid.

Hairs frequently up to $130-150 \mu \mathrm{m}, 6-7$-septate, regularly tapering, straight, narrow, basally $3-4 \mu \mathrm{m}$ wide, apex blunt in young hairs but tapered in longer hairs; wall basally $0.5 \mu \mathrm{m}$ thick in cotton blue, apically thin. Hairs often glued together by their exudations, when fresh covered with hyaline, amorphous lumps of variable size, but mostly smooth at their apices; after drying the lumps visible in water mounts, but gradually dissolving in other mountants. In Melzer's reagent and especially in heated cotton blue hairs
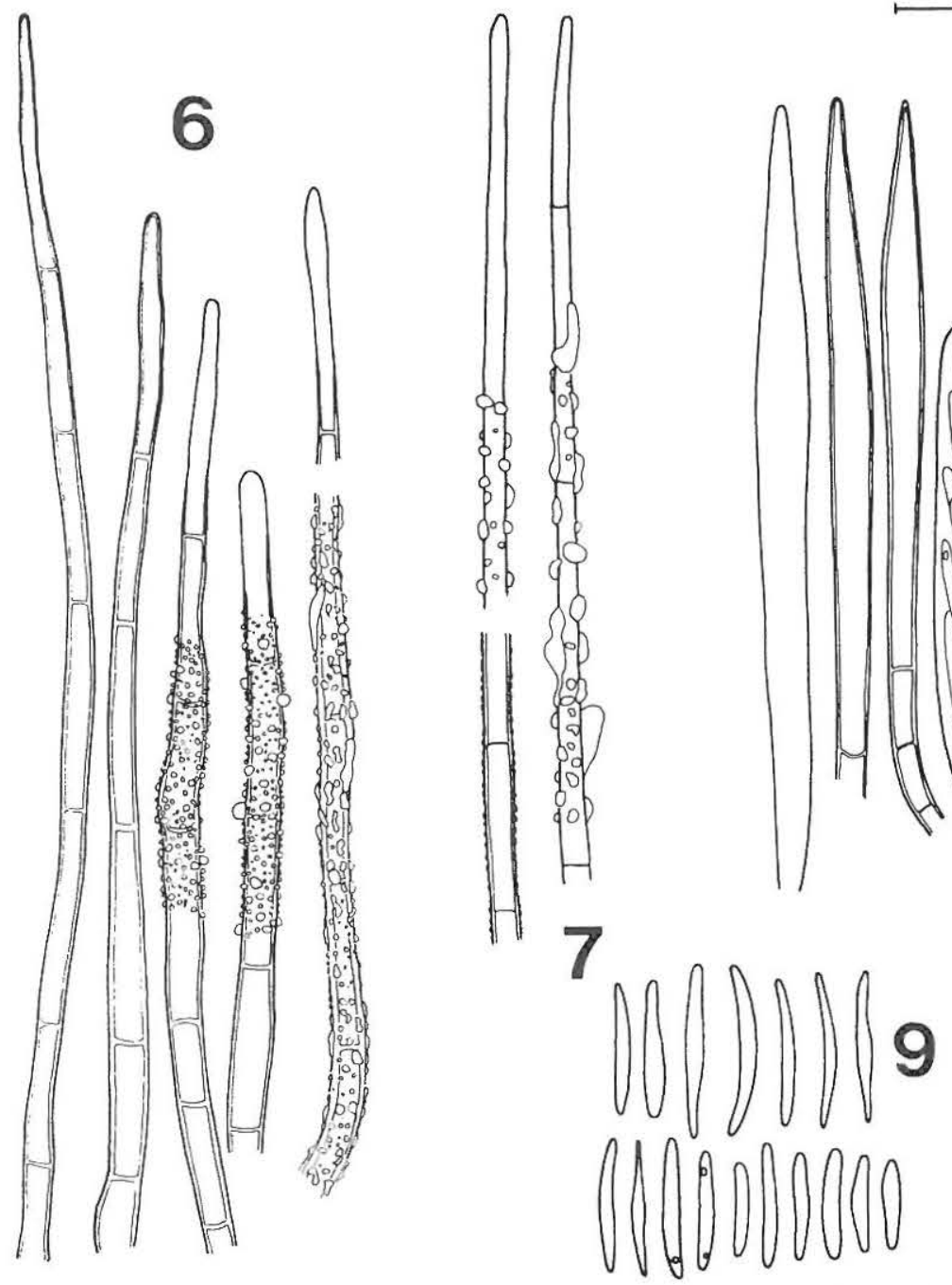
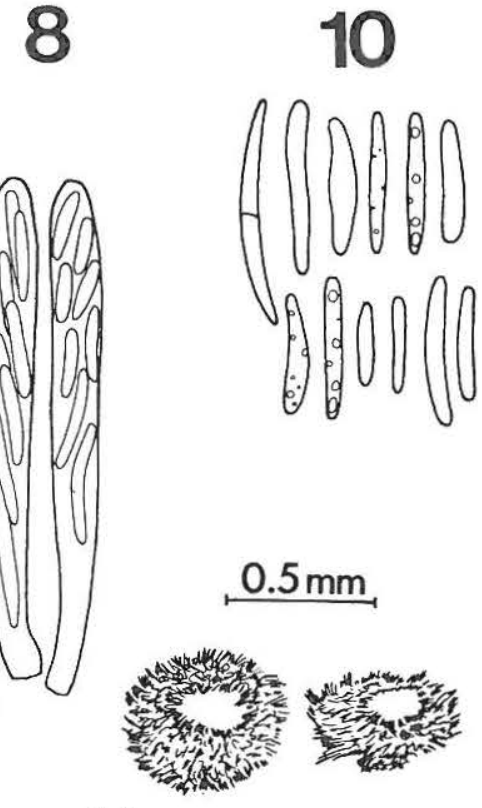

11

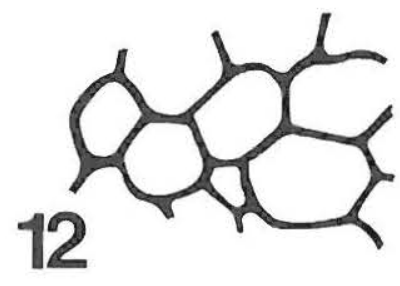

Figs. 6-12. Albotricha laetior, scale $50 \mu \mathrm{m}$. - 6: Hairs in cotton blue, the hair on the right mounted in water. 7: Hairs in water from fresh material. - 8: Asci and paraphyses in cotton blue. - 9-10: Spores in cotton blue and Melzer's reagent. - 11: Apothecia in dried condition. - 12: Ectal excipulum in lactic acid. - Figs. 6, 8, 9, 12 from holotype; the others from Huhtinen 84/14. 
often totally smooth, but some with hyaline, roundish, swollen lumps or with small, firmly attached true warts. In $10 \% \mathrm{KOH}$ exudations still persistent but lost when gently heated.

Asci narrow, cylindrical, $40-50 \times 4-5 \mu \mathrm{m}$, eightspored, amyloid without $\mathrm{KOH}$ pretreatment, walls negative in Congo red (in contrast to other structures of the apothecia). Spores cylindrical-subfusoid to fusoid, $10-18(-20.5) \times 1.3-2.0 \mu \mathrm{m}$ in dried material (cotton blue), lowermost spores typically largest and most fusoid, usually spores aseptate (once seen to become one-septate), hyaline, aguttulate or with a few minute guttules. Paraphyses clearly lanceolate, one- to three-septate below, $4-5 \mu \mathrm{m}$ wide, wall $0.5 \mu \mathrm{m}$ in cotton blue, smooth, exceeding the asci by $20-30 \mu \mathrm{m}$.

Albotricha laetior is the second lignicolous species in the genus, the other being $A$. minuta Raitv., reported from East Siberia and the Soviet Far East (Raitviir 1973). After the studies of Karsten (1870, 1871), a new collection was reported by Nannfeldt (1942), who discovered that another specimen from Mustiala taken by K. Starbäck represented this species. The specimen fruited on decorticated Salix wood, like the present material. Rubus idaeus thought to be the 'correct' substrate of the species, also actually represents a lignicolous substrate.

To my knowledge this species has been found outside Finland only in Estonia (Järva \& Parmasto 1980), on Rubus idaeus. Dennis (1949) erroneously stated that the fungus had been reported from Sweden, referring to Nannfeldt (1942), who treated only Finnish material. The collections have been made early in the season, which might partly explain why such a conspicuous discomycete has been collected so rarely. Macroscopically it looks very like Lachnum bicolor (Bull.: Fr.) Karst., and further older specimens may be hidden among material of this common species.

My collection is indistinguishable from Karsten's original material. The hairs are typically smooth, but modified by abundant exudations, which are hyaline, amorphous and quite easily removed, e.g. with heated, $10 \% \mathrm{KOH}$. In contrast, the small granules of, e.g.
L. bicolor persist in $20 \% \mathrm{KOH}$ even when strongly heated. In unheated Melzer's reagent the hairs of $A$. laetior may look as though they are firmly granulated, but incipient changes are indicated by the appearance of modified, swollen 'guttules' on the hairs. In heated cotton blue most of the hairs are smooth. The basal and apical parts, especially the latter, do not seem to have any exudations, since they are smooth both when fresh and in water-mounted dry material. Mounting in water does not change the appearance of the exuded material, except if strongly heated.

The basal spores of the asci differ from the apical ones: the lowermost two or three are longer and more fusiform than the rest, causing distinct sporal dimorphism in squash mounts. Apparently both types are released by the fungus.

When describing the species as a subspecies of Lachnea acutipila Karst., Karsten (1870) cited only one collection, which is undoubtedly that now bearing the number 2503, here considered a holotype of the species. No other collections exist under this name in $\mathrm{H}$.

\section{References}

Dennis, R.W.G. 1949: A revision of the British Hyaloscyphaceae with notes on related European species. - Mycol. Papers 32: $1-97$.

Döbbeler, P. 1984: Symbiosen zwischen Gallertalgen und Gallertpilzen der Gattung Epigloea (Ascomycetes). Nova Hedwigia, Beih. 79: 203-239.

Järva, L. \& Parmasto, E. 1980: Eesti seente koondnimestik. List of Estonian fungi with host index and bibliography. - Scripta Mycol. 7: 1-331.

Karsten, P. 1870: Symbolae ad Mycologiam fennicam 1. Not. Sällsk. Fauna Flora Fenn. Förh. 11: 211-268.

- 1871: Mycologia fennica 1. Discomycetes. - 263 pp. Helsingfors.

Korf, R.P. \& Kohn, L.M. 1980: Revisionary studies in the Hyaloscyphaceae 1. On genera with 'glassy' hairs. Mycotaxon 10: 503-512.

Nannfeldt, J.A. 1942: Contributions to the mycoflora of Sweden. - Svensk Bot. Tidskr. 36: 287-300.

Raitviir, A. 1973: Some new species of Albotricha. - Fol. Crypt. Eston. 2: 13-15.

Raschle, P. 1977: Taxonomische Untersuchungen an Ascomyceten aus der Familie der Hyaloscyphaceae Nannfeldt. - Sydowia 29: 170-236. 